\title{
AIR DEFENCE IDENTIFICATION ZONE: UPAYA MENJAGA KEDAULATAN WILAYAH UDARA INDONESIA
}

\author{
Afrizal Razqi ${ }^{1}$ \\ 1Fakultas Ilmu Sosial dan Hukum, Universitas Negeri Surabaya \\ Corresponding Authors Email: afrizalrazqi15@gmail.com
}

Received: February 28, 2021, Accepted: March 28, 2021 /Published: April 30, 2021 DOI: https://doi.org/10.31764/jmk.v12i1.4265

\begin{abstract}
Air is an inseparable part of a country, a country's sovereignty over land and sea also means sovereignty over airspace. As an international community, it is only natural that Indonesia's airspace is used for the common interest of supporting population mobility and economic improvement. However, Indonesian sovereignty over airspace is still being violated by foreign aircraft. Air Defence Identification Zone (ADIZ) is a zone for identification of foreign aircraft before entering the airspace. The determination of ADIZ Indonesia needs to be accompanied by various preparations including improving positive laws regarding airspace security, completing air defense system infrastructure, and building an understanding of the concept of ADIZ Indonesia with neighboring countries directly bordering Indonesia. This paper uses a normative legal research method using a descriptive analysis approach, a legal material search technique uses a secondary data source obtained through a literature study, and a study analysis uses qualitative analysis. The results of the writing show that there are legal gaps and gaps in the determination of administrative sanctions fines, the lack of the number of radars belonging to the Indonesian Air Force under the National Defense Force in protecting Indonesian airspace, and the heavy-duty of the Ministry of Foreign Affairs to build the trust of neighboring countries amid the dynamics of the South China Sea territorial conflict if the government determines ADIZ Indonesia.
\end{abstract}

Keywords: Airspace; Sovereignty; ADIZ.

ABSTRAK
Udara merupakan bagian yang tidak terpisahkan dari suatu negara,
kedaulatan suatu negara akan daratan dan lautan juga berarti kedaulatan
akan wilayah udara. Sebagai masyarakat Internasional, sudah sewajarnya
wilayah udara Indonesia dimanfaatkan untuk kepentingan bersama guna
mendukung mobilitas penduduk sampai peningkatan ekonomi. Namun
kedaulatan Indonesia akan wilayah udara masih marak dilanggar oleh
pesawat udara asing. Air Defence Identification Zone (ADIZ) merupakan
zona identifikasi pesawat udara asing sebelum memasuki wilayah udara.
Penetapan ADIZ Indonesia perlu dibarengi dengan pelbagai kesiapan 
meliputi penyempurnaan hukum positif mengenai pengamanan wilayah udara, melengkapi infrastruktur sistem pertahanan udara, dan membangun kesepahaman konsep ADIZ Indonesia dengan negara tetangga yang berbatasan langsung dengan Indonesia. Menggunakan metode penelitian hukum normatif dengan menggunakan pendekatan deskriptif analisis. Teknik penelusuran bahan hukum menggunakan sumber data sekunder yang didapat melalui studi kepustakaan. Analisis kajian menggunakan analisis kualitatif. Hasil penulisan menunjukan bahwa ada celah dan kekosongan hukum dalam penetapan denda sanksi administratif, kurangnya jumlah radar milik TNI AU dibawah Kohanudnas dalam melindungi wilayah udara Indonesia, dan tugas berat Kementerian Luar Negeri untuk membangun kepercayaan negara tetangga ditengah dinamika konflik teritorial Laut China Selatan apabila pemerintah menetapkan ADIZ Indonesia.

Kata kunci: Wilayah Udara; Kedaulatan; ADIZ.

\section{PENDAHULUAN}

Udara adalah salah satu bagian yang tidak terpisahkan dari bagian suatu negara, baik negara berdimensi dua meliputi daratan dan udara maupun negara berdimensi tiga meliputi daratan, udara dan laut. Indonesia merupakan negara yang memiliki tiga dimensi dalam wilayahnya, ${ }^{1}$ hal ini menjadi salah satu keunggulan Indonesia dalam pengelolaan wilayah untuk mencapai sebesar-besarnya kemakmuran rakyat. Meskipun Indonesia secara de facto melalui Pasal 33 ayat (3) Undang-undang Dasar Negara Republik Indonesia 1945 belum meletakkan wilayah udara sebagai bagian dari kekayaan alam yang dapat dipergunakan untuk mensejahterakan rakyat.

Letak wilayah Indonesia yang secara geografis membelah samudera Hindia dan samudera Pasifik serta memisahkan benua Asia dan benua Australia menjadikan posisi Indonesia sangat strategis untuk dilalui oleh pesawat udara. Letak geografis Indonesia yang strategis membuat perlintasan di wilayah udara ramai dilalui oleh pelbagai pesawat udara

\footnotetext{
${ }^{1}$ B. Setiani, “Konsep Kedaulatan Negara Di Ruang Udara Dan Upaya Penegakan Pelanggaran Kedaulatan Oleh Pesawat Udara Asing," Jurnal Konstitusi 14, no. 3 (2017).
} 
asing untuk mengkoneksikan satu wilayah dengan wilayah lainnya, efisiensi waktu dan bahan bakar avtur menjadi poin penting operator pesawat udara asing dalam melintasi wilayah udara Indonesia. Padatnya lalu lintas udara di wilayah udara Indonesia berbanding terbalik dengan banyaknya pelanggaran wilayah udara Indonesia oleh pesawat udara asing, baik oleh pesawat udara sipil asing maupun pesawat udara negara asing. ${ }^{2}$

Sebagai bagian dari masyarakat Internasional, dalam pemanfaatan wilayah udara Indonesia memiliki kewajiban untuk mengakomodir kepentingan masyarakat internasional dengan aturan-aturan yang telah disepakati bersama dalam hukum internasional. Hukum Indonesia mengenai wilayah udara saat ini belum dapat bekerja secara maksimal dalam mengamankan, hal ini disebabkan oleh perspektif penataan dan pengelolaan wilayah udara Indonesia yang selama ini berbasis pada keselamatan penerbangan pesawat udara sipil, sedang perspektif pertahanan dan penjagaan terhadap kedaulatan wilayah udara masih belum mendapat posisi utama sehingga penekanan terhadap pelanggar wilayah udara Indonesia masih belum dapat ditangani secara optimal. ${ }^{3}$

Tentara Nasional Republik Indonesia, melalui Undang-undang Nomor 34 Tahun 2004 tentang Tentara Nasional Indonesia diamanatkan untuk menegakkan kedaulatan negara, mempertahankan keutuhan wilayah, dan melindungi bangsa Indonesia dari ancaman dan gangguan terhadap keutuhan negara. Khususnya kepada Tentara Nasional Indonesia Angkatan Udara, memegang peranan penting untuk

2 D Halim, “Sepanjang 2018 TNI AU Catat Ada 127 Kasus Pelanggaran Wilayah Udara Nasional," Kompas (Jakarta, December 2018).

3 D. D Marsono, "Konsep Kedaulatan Negara Di Ruang Udara Dan Upaya Penegakan Pelanggaran Kedaulatan Oleh Pesawat Udara Asing," Jurnal Pertahanan E Bela Negara 8, no. 2 (2018): 2. 
melaksanakan tugas di bidang pertahanan udara, penegakkan hukum, dan menjaga keamanan di wilayah udara yuridiksi nasional.

Peraturan Pemerintah Nomor 4 Tahun 2018 tentang Pengamanan Wilayah Udara Republik Indonesia, dalam pasal 6 ayat (2) menyebutkan bahwa selain menetapkan kawasan udara terlarang dan kawasan udara terbatas, pemerintah juga dapat menetapkan zona identifikasi pertahanan udara atau yang lebih dikenal sebagai Air Defence Identification Zone (ADIZ). ADIZ merupakan zona identifikasi yang diperuntukkan untuk mengetahui detail informasi rencana penerbangan dari pesawat udara asing yang akan melintasi wilayah udara suatu negara melalui deteksi radar pertahanan udara, zona ini bertujuan untuk kepentingan pertahanan dan keamanan wilayah udara dan umumnya terbentang dari wilayah udara daratan hingga wilayah udara di atas laut kedaulatan dan dapat diperluas sesuai dengan kesepakatan pemanfaatan wilayah udara bersama negara tetangga. ${ }^{4}$

Penetapan ADIZ diluar wilayah daratan dan lautan suatu negara tidak dimaksudkan untuk memperlebar kedaulatan, melainkan sebagai zona untuk melakukan identifikasi sebelum pesawat udara asing memasuki wilayah udara kedaulatan. Pesawat udara sipil asing maupun pesawat udara negara asing yang berada dalam zona tersebut diwajibkan untuk memberikan laporan mengenai rencana penerbangan kepada negara yang menetapkan $A D I Z$, apabila kewajiban tersebut tidak dilaksanakan maka akan diberikan tindakan intersepsi oleh negara pemilik ADIZ. ${ }^{5}$

Dasar hukum dari penetapan ADIZ adalah praktik kebiasaan internasional dalam menetapkan zona identifikasi sesuai dengan

4 Ibid

${ }^{5}$ A. Supriadhie, Penerapan Air Defence Identification Zone (ADIZ) Di Wilayah Ruang Udara Oleh Negara (Jakarta, 2016). 
kepentingan negara masing-masing. Secara legalitas, Indonesia telah memiliki dasar untuk menetapkan ADIZ di atas wilayah udara baik meliputi daratan maupun lautan. Penetapan ADIZ akan mempermudah tugas pokok dan fungsi TNI AU untuk mempertahankan, menegakkan hukum dan menjaga keamanan wilayah udara yurisdiksi nasional. Belum ditetapkannya Indonesia ADIZ oleh pemerintah akan mempersempit ruang gerak TNI AU dalam mencegah dan menurunkan angka pelanggaran wilayah udara Indonesia, selain itu pelanggaran yang selama ini terjadi masih dipandang sebagai pelanggaran izin terbang dan administratif, tidak dipandang sebagai pelanggaran terhadap kedaulatan negara.

Studi ini dilakukan untuk mengetahui tindakan yang perlu dilakukan oleh pemerintah dalam menetapkan ADIZ Indonesia sesuai dengan Pasal 6 ayat (2) dan Pasal 9 ayat (1) dan (2) PP No. 4 Tahun 2018 tentang Pengamanan Wilayah Udara Republik Indonesia, meliputi: penyempurnaan hukum positif pengamanan wilayah udara, peningkatan kapasitas radar pertahanan udara, dan diplomasi dengan negara tetangga.

\section{METODOLOGI}

Tulisan ini menggunakan metode penelitian hukum normatif dengan pendekatan deskriptif analisis. Teknik penelusuran bahan hukum menggunakan sumber data sekunder yang didapat melalui studi kepustakaan6 ${ }^{6}$. Data sekunder yang digunakan dalam tulisan ini adalah Peraturan Perundang-undangan, buku, karya ilmiah, hasil penelitian, jurnal, dan artikel ilmiah yang membahas mengenai ruang udara, wilayah

6 Depri Liber Sonata, "METODE PENELITIAN HUKUM NORMATIF DAN EMPIRIS: KARAKTERISTIK KHAS DARI METODE MENELITI HUKUM," FIAT JUSTISIA:Jurnal Ilmu Hukum (2015). 
udara, kedaulatan serta tantangan pemerintah kedepan dalam menetapkan $A D I Z$, dan analisis kajian menggunakan analisis kualitatif.

\section{PEMBAHASAN}

\section{A. Penyempurnaan Hukum Positif Pengamanan Wilayah Udara}

Air Defence Identification Zone (ADIZ) merupakan penetapan suatu ruang udara khusus tertentu dimana semua pesawat udara yang berada dalam zona tersebut diwajibkan untuk mematuhi prosedur identifikasi berkenaan dengan lalu lintas udara dan rencana penerbangannya, $A D I Z$ umumnya terbentang dari wilayah teritorial negara yang bersangkutan hingga mencapai perbatasan baik wilayah daratan maupun lautan dengan negara tetangga atau laut bebas. ${ }^{7}$

ADIZ bekerja melalui mekanisme pelaporan detail informasi mengenai identitas, tujuan, dan rencana penerbangan yang dilakukan oleh pilot pesawat udara tersebut kepada petugas Air Traffic Control (ATC) yang terkoneksi dengan radar pertahanan udara milik militer, apabila pesawat udara tidak melaksanakan prosedur yang telah ditetapkan dalam ADIZ maka militer negara tersebut dapat melakukan pengejaran seketika, pengenalan secara visual, pembayangan, penghalauan, hingga melaksanakan pemaksaan mendarat di lapangan terbang yang telah ditentukan.

Dasar hukum pendirian ADIZ oleh suatu negara adalah praktik kebiasaan internasional untuk mempertahankan kedaulatan dan keamanan wilayah udaranya dari pelbagai bentuk ancaman, 8 Piagam Persatuan Bangsa-Bangsa tentang Hak Bela Diri Negara melalui Pasal 51 juga menjelaskan bahwa hak membela diri merupakan sesuatu yang

\footnotetext{
7 Lainatussara, "Pentingnya Air Defence Identification Zone Di Indonesia," Kanun Jurnal Ilmu Hukum 21, no. 3 (2019): 460.

${ }_{8}$ Markas Besar TNI AU, Buku Panduan Perwira Hukum Tentara Nasional Indonesia Angkatan Udara (Jakarta: Diskumau, 2000).
} 
melekat kepada setiap negara dan dapat diperluas menjadi hak melindungi diri dari ancaman yang dihadapi. Konvensi Chicago 1944 yang mengatur mengenai ketentuan-ketentuan hukum udara internasional juga menegaskan dalam Pasal 1-3 bahwa ruang udara sepenuhnya tunduk pada kedaulatan dari negara kolong yang bersifat "complete and exclusive".

Negara kolong memiliki hak secara penuh dan utuh untuk mengatur ruang udara yang berada di atas wilayah teritorialnya baik daratan maupun lautan, ruang udara negara kolong juga bersifat ekslusif sehingga apabila ada pesawat udara sipil asing dan pesawat udara negara asing ingin memasuki wilayah udara negara kolong harus meminta izin terlebih dahulu kepada negara kolong, ${ }^{9}$ hal inilah yang mendasarkan hukum internasional tidak memberikan hak lintas damai melalui ruang udara.

Ruang udara yang "complete and exclusive" inilah menjadikan negara kolong berdaulat atas wilayah udaranya, negara kolong memiliki kendali penuh atas ruang udara dan memiliki yurisdiksi hukum sendiri yang wajib dipatuhi oleh pesawat udara yang melintasi ruang udara negara kolong. Muctar Kusumatmadja menuturkan bahwa "Negara dikatakan berdaulat karena kedaulatan merupakan sifat atau ciri hakiki negara, dan bila dikatakan negara itu berdaulat dimaksudkan negara itu mempunyai kekuasaan tertinggi". ${ }^{10}$

Indonesia telah memiliki instrumen hukum untuk menjaga dan mempertahankan kedaulatan negara melalui Pasal 4 Undang-undang Nomor 3 Tahun 2002 tentang Pertahanan Negara, menjelaskan bahwa pertahanan negara bertujuan untuk menjaga dan melindungi kedaulatan negara, keutuhan wilayah Negara Kesatuan Republik Indonesia, dan

\footnotetext{
${ }^{9}$ Handini, "Kedaulatan Wilayah Udara Di Atas Alur Laut Kepulauan Indonesia (ALKI)," Jurnal Rechts Vinding 8, no. 2 (2019): 280.

10 M Kusumatmadja, Pengantar Ilmu Hukum Internasional (Bandung: Putra Bardin, 1999).
} 
keselamatan segenap bangsa dari segala bentuk ancaman. Selain itu Pasal 4 Undang-undang Nomor 43 Tahun 2008 tentang Wilayah Negara, juga menjelaskan bahwa wilayah negara meliputi darat, wilayah perairan, dasar laut, dan tanah dibawahnya serta ruang udara di atasnya, termasuk seluruh sumber kekayaan yang terkandung di dalamnya.

Dua undang-undang tersebut menjadi dasar dalam menetapkan pola pertahanan wilayah Negara Kesatuan Republik Indonesia dari ancaman dan gangguan stabilitas keamanan, lebih jauh lagi Pasal 5 Undangundang Nomor 1 Tahun 2009 tentang Penerbangan menjelaskan bahwa Negara Kesatuan Republik Indonesia berdaulat penuh dan eksklusif atas wilayah udara Republik Indonesia. Kedaulatan atas ruang udara inilah yang menjadi wewenang dan tanggung jawab pemerintah dalam menetapkan pengaturan ruang udara untuk kepentingan penerbangan, perekonomian nasional, pertahanan dan keamanan negara, serta pelbagai kepentingan lainnya. ${ }^{11}$

PP Nomor 4 Tahun 2018 tentang Pengamanan Wilayah Udara Republik Indonesia telah jauh mengatur mengenai mekanisme pengamanan wilayah udara yang sebelumnya hanya menggunakan Pasal 9 Undang-undang Nomor 1 Tahun 2009 tentang Penerbangan, melalui terbitnya PP Nomor 4 Tahun 2018 tentang Pengamanan Wilayah Udara Republik Indonesia, pemerintah dapat menetapkan ADIZ sebagai langkah preventif untuk menekan angka pelanggaran wilayah udara Indonesia.

Penetapan kawasan udara terlarang seperti: ruang udara di atas istana presiden, ruang udara di atas instalasi nuklir, dan ruang udara di atas objek vital nasional yang bersifat strategis. Kawasan udara terbatas seperti: markas besar Tentara Nasional Indonesia, pangkalan udara Tentara Nasonal Indonesia, kawasan latihan militer, kawasan operasi

11 Setiani, “Konsep Kedaulatan Negara Di Ruang Udara Dan Upaya Penegakan Pelanggaran Kedaulatan Oleh Pesawat Udara Asing." 
militer, kawasan latihan penerbangan militer, kawasan latihan penembakan militer, kawasan peluncuran roket dan satelit, serta ruang udara yang digunakan untuk penerbangan orang setingkat kepala negara atau kepala pemerintahan belum cukup untuk menjaga wilayah udara negara dari pelbagai bentuk pelanggaran kedaulatan wilayah udara.

Mengingat kawasan udara terlarang dan kawasan udara terbatas hanya menjangkau titik-titik lokasi yang telah ditetapkan saja, tidak menjangkau seluruh wilayah udara Indonesia, untuk itu perlu ditetapkan ADIZ guna memaksimalkan perlindungan dan pengamanan seluruh wilayah udara Indonesia dari masuknya pesawat udara asing yang tidak memiliki izin melintas dan membawa kepentingan-kepentingan tertentu. ${ }^{12}$

Penetapan ADIZ oleh pemerintah perlu dibarengi dengan penyempurnaan hukum positif yang mengatur mengenai pengamanan wilayah udara Indonesia, mengingat hukum positif yang saat ini ada dalam beberapa pembahasan masih terdapat celah hukum. Pengaturan mengenai besaran biaya yang harus dibayarkan oleh pesawat udara sipil setelah mendapat tindakan pemaksaan pendaratan sebelumnya menggunakan Peraturan Direktur Jendral Perhubungan Udara Nomor: SKEP/195/IX/2008 tentang Petunjuk Pelaksanaan Persetujuan Terbang (Flight Approval) dimana dalam Pasal 17 huruf (b) menjelaskan bahwa terhadap pesawat udara yang tidak memiliki persetujuan terbang (Flight Approval) dikenakan biaya pendaratan tambahan (landing fee) sebesar Rp 60.000.000,- (enam puluh juta rupiah).

Setelah adanya PP Nomor 4 Tahun 2018 tentang Pengamanan Wilayah Udara Republik Indonesia, dalam Pasal 11 angka (1) ketentuan pengenaan sanksi administratif dan besaran denda administratif menjadi paling banyak Rp 5.000.000.000,- (lima milyar rupiah). Denda ini

12 Ant, “Sudah Saatnya Indonesia Memiliki Adiz,” Media Indonesia (Jakarta, 2018). 
dikenakan apabila pesawat udara asing yang tidak terjadwal melakukan penerbangan dari dan ke atau melalui wilayah udara Indonesia dan tidak memiliki izin diplomatik, izin keamanan dan persetujuan terbang yang masing-masing dikeluarkan oleh Kementerian Perhubungan, Kementerian Pertahanan dan Kementerian Luar Negeri.

Pasal 11 angka (1) PP Nomor 4 Tahun 2018 tentang Pengamanan Wilayah Udara Republik Indonesia mengenai besaran denda sanksi administratif hanya mengatur mengenai denda maksimal yang dapat diberlakukan kepada pesawat udara asing yang melanggar wilayah udara, sedang pengaturan denda minimal tidak dicantumkan dalam pengaturan tersebut. Tidak adanya kepastian hukum dalam pengaturan lebih rinci mengenai penghitungan besaran denda sanksi administratif membuat asas kepastian hukum belum dapat dipenuhi. Selain itu, Pasal 11 angka (1) PP Nomor 4 Tahun 2018 tentang Pengamanan Wilayah Udara Republik Indonesia dapat dikatakan belum operasional mengingat peraturan turunan dari Pasal 11 berupa Peraturan Menteri Perhubungan yang mengatur mengenai tata cara pengenaan sanksi administratif belum ditetapkan, ketiaadaan Peraturan Menteri Perhubungan ini menyebabkan kekosongan hukum jika terjadi pemaksaan mendarat pesawat udara asing oleh TNI AU.13

Meskipun Pasal 5 UU No. 1 Tahun 2009 tentang Penerbangan menjelaskan bahwa Indonesia berdaulat penuh dan eksklusif atas wilayah udara Republik Indonesia, kepastian hukum merupakan hal yang mutlak untuk menciptakan ketertiban dalam penegakan kedaulatan wilayah udara, jangan sampai tindakan pemaksaan mendarat yang dilakukan oleh TNI AU menyebabkan pesawat udara asing terjebak dalam ketidak pastian hukum.

13 D Risdiarto, "Kendala Hukum Penindakan Terhadap Pesawat Udara Sipil Asing Tidak Berizin Yang Memasuki Wilayah Udara Indonesia," Jurnal Legislasi Indonesia 16, no. 3 (2019): 363. 
Pada 14 Januari 2019, Pesawat kargo Ethiopia Airlines ETH 3728 diintersepsi dan dipaksa melakukan pendaratan di bandara Hang Nadim, Batam, Kepulauan Riau oleh dua pesawat tempur F-16 TNI AU karena melakukan penerbangan tidak berjadwal. Penanganan pasca pemaksaan mendarat yang lambat hingga lebih dari 3 hari karena mekanisme penetapan besaran denda sanksi administratif yang belum ada, mengakibatkan maskapai Ethiopia Airlines melayangan nota keberatan karena pesawat kargo mereka tidak ditangani secara cepat dan merugikan operasional maskapai. ${ }^{14}$

Kementerian Perhubungan, sebagaimana yang diamanatkan dalam PP Nomor 4 Tahun 2018 tentang Pengamanan Wilayah Udara Republik Indonesia harus segera menerbitkan Peraturan Menteri tentang tata cara pengenaan sanksi administratif guna mengisi kekosongan hukum. Idealnya dalam Peraturan Menteri tersebut memuat rincian pengeluaran biaya yang telah dikeluarkan oleh TNI AU pada saat melakukan tindakan pengenalan secara visual, pembayangan, penghalauan, dan pemaksaan mendarat. Meliputi biaya: operasional pesawat tempur selama melakukan tindakan di udara, penggunaan senjata untuk menghancurkan pesawat udara negara asing, dan biaya lain terkait seperti pemindahan pesawat udara asing yang telah berhasil di paksa mendarat dari lapangan terbang ke hangar pesawat, biaya parkir pesawat udara asing, dan biaya penyimpanan barang beserta alat bukti.

Rincian pengeluaran biaya ini akan melindungi keuangan negara khususnya Anggaran Pendapatan dan Belanja Negara dari pengeluaran yang tidak terduga, sehingga seluruh pengeluaran biaya operasional pelaksanaan pemaksaan mendarat pesawat tempur TNI AU dapat tergantikan. Selain itu, pemberian wewenang kepada Direktorat Jenderal

14 A. P Taher, “Mekanisme Force Down Disusun Atasi Gugatan Seperti Dari Ethiopia,” Tirto.Id. 
Perhubungan Udara untuk menjual atau melelang pesawat udara asing yang telah dilaksanakan tindakan pemaksaan mendarat apabila pemiliknya tidak membayar denda sanksi administratif sesuai dengan ketentuan yang diatur juga dapat menjadi alternatif pendapatan negara non-pajak. ${ }^{15}$

\section{B. Peningkatan Kapasitas Radar Pertahanan Udara}

Terdapat beberapa unsur untuk menunjang kinerja ADIZ apabila diterapkan oleh pemerintah, unsur tersebut dipengaruhi oleh perkembangan teknologi militer yang selalu aktual meliputi sistem radar pertahanan udara, jangkauan frekuensi satelit dan alat komunikasi, alih teknologi sistem persenjataan dan alokasi anggaran pertahanan negara sesuai dengan APBN untuk Kementerian Pertahanan.

Masing-masing unsur tersebut adalah: kekuatan alat utama sistem persenjataan TNI AU seperti jenis pesawat tempur, satelit dan alat komunikasi, radar militer dalam menjangkau wilayah ADIZ, artileri pertahanan udara, pangkalan udara, Sector Operational Center (SOC), sistem informasi dan komunikasi yang terintegrasi seperti Transmittion Data Air Situation (TDAS), dan kapal militer yang memiliki kemampuan pertahanan udara dan berlayar di dalam wilayah ADIZ serta terintegrasi dengan sistem pertahanan udara milik Komando Pertahanan Udara Nasional, Komando Utama Fungsional yang didirikan oleh TNI AU untuk menjaga wilayah udara Indonesia.

Komando Pertahanan Udara Nasional atau Kohanudnas bertugas menyelenggarakan upaya pertahanan dan keamanan atas wilayah udara nasional secara mandiri atau berkerja sama dengan Komando Utama Operasional lainnya, tujuan dari pembentukan Kohanudnas pada tahun

\footnotetext{
15 R. A Nugraha, 'Menyempurnakan Hukum Positif Pengamanan Wilayah Udara Nasional', Hukumonline.Com,2019<https://jurnal.hukumonline.com/berita/baca/lt5d96ccae4b35c/menyemp urnakan-hukum-positif-pengamanan-wilayah-udara-nasional-oleh--ridha-adityanugraha?page $=$ all, $>$ [accessed 18 February 2021].
} 
1958 adalah mewujudkan kedaulatan dan keutuhan serta kepentingan lain dari Indonesia atas wilayah udaranya. Selain itu, Kohanudnas juga menyelenggarakan pembinaan administrasi dan kesiapan operasi unsurunsur pertahanan udara TNI AU dan melaksanakan siaga operasi untuk mendukung tugas pokok TNI.16

Dalam operasionalnya, Kohanudnas membawahi 4 Komando Sektor Pertahanan Udara Nasional atau Kosekhanudnas yang masing-masing berkedudukan di wilayah area pengawasan. Kosekhanudnas I berkedudukan di Daerah Khusus Ibukota Jakarta dan bertugas mengendalikan operasi pertahanan udara di wilayah udara Ibukota, Kosekhanudnas II berkedudukan di kota Makassar dan bertugas mengendalikan operasi pertahanan udara di wilayah Jawa Timur, Bali, Nusa Tenggara Barat, Pulau Sulawesi, Kalimantan Timur dan Kalimantan tengah. Kosekhanudnas III berkedudukan di kota Medan dan bertugas mengendalikan operasi pertahanan udara di wilayah Jambi, Riau dan Kepulauan Riau, Sumatera Barat, Sumatera Utara dan Nanggro Aceh Darussalam. Kosekhanudnas IV berkedudukan di Kota Biak dan bertugas mengendalikan operasi pertahanan udara di wilayah Papua, Papua Barat, Maluku dan Maluku Utara.

Dalam menjalankan tugas pokok dan fungsinya, Kosekhanudnas didukung oleh pelbagai satuan radar yang membawahi area masingmasing. Radar memiliki fungsi vital dalam sistem pertahanan udara, ketiadaan radar yang mengawasi jangkauan area wilayah pertahanan udara akan berakibat fatal dan memudahkan pesawat udara asing dalam melintasi dan bermanuver di wilayah udara. Radar berperan sebagai sistem deteksi dini ancaman terhadap pertahanan dan keamanan sebelum pesawat tempur TNI AU melakukan intersepsi terhadap pesawat udara

\footnotetext{
16 Tentara Nasional Indonesia Angkatan Udara., “Tugas Kohanudnas,” Tni-Au.Mil.Id.
} 
asing. Saat ini TNI AU memiliki 20 titik radar udara yang disebut sebagai satuan radar dibawah Kohanudnas, dengan rincian Kosekhanudnas I dan Kosekhanudnas II membawahi 6 satuan radar, serta Kosekhanudnas III dan Kosekhanudnas IV membawahi 4 satuan radar.

Penempatan satuan radar Kohanudnas sebagian besar masih terpusat di wilayah Indonesia bagian barat, sedang wilayah Indonesia bagian timur masih banyak yang belum terjangkau oleh radar TNI AU.17 Wilayah yang belum terjangkau deteksi satuan radar meliputi: bagian barat Sumatera Barat, Bengkulu, perbatasan Kalimantan Barat dengan Sarawak, Malaysia, wilayah utara kepulauan Maluku, wilayah utara Papua Barat dan wilayah kepulauan Nusa Tenggara Timur.

Pembangunan sistem pertahanan udara, utamanya memperbaiki dan memperbaharui sistem radar yang telah ada, dan mengadakan satuan radar baru untuk wilayah yang belum terjangkau deteksi radar mutlak dilakukan untuk memperbaiki dan memperkuat pertahanan udara sebelum pemerintah menetapkan ADIZ. Pada tahun 2014, Kepala Dinas Penerangan TNI AU, Marsekal TNI Hadi Tjahjanto menuturkan bahwa idealnya radar TNI AU berjumlah 32 titik. ${ }^{18}$ Kekurangan 12 radar akan diadakan secara bertahap dan dipenuhi pada tahun 2024, pengadaan radar baru juga harus memperhatikan efektivitas penggunaan anggaran pertahanan negara, utamanya prioritas ancaman di masa damai ini.

Radar baru harus dapat mendukung pelbagai informasi yang dibutuhkan oleh Kohanudnas dalam pengelolaan ADIZ, seperti pemanggilan dan komunikasi dengan pesawat udara asing, informasi nomor dan tipe pesawat, ketinggian pesawat, kecepatan pesawat, estimasi waktu pesawat selama berada dalam $A D I Z$, dan menunjukkan posisi

\footnotetext{
17 A Yudhistira, “Over-The-Horizon Radar (OTHR) Untuk Menjaga Wilayah Udara Dan Laut Indonesia," Jurnal Pertahanan 5, no. 2 (2015): 139.

18 T Chairil, "Cek Fakta: 19 Titik Di Udara Dan 11 Titik Di Maritim, Apakah Sistem Radar Yang Disebut Jokowi Sudah Efektif?," The Conversation.Com.
} 
koordinat sesuai dengan latitude/longitude. Penguasaan ruang udara oleh TNI AU, nantinya akan sejalan dengan teori penguasaan Cooper dimana kedaulatan suatu negara ditentukan oleh kemampuan negara itu untuk mempertahankan dan menguasai ruang udara yang ada di atas wilayah daratan dan lautannya. ${ }^{19}$

C. Diplomasi Negara Tetangga terkait Penetapan Air Defence Identification Zone

Pada tahun 2017, Kohanudnas, Kementerian Perhubungan, Kementerian Pertahanan, Badan Nasional Pengelolaan Perbatasan, dan pemangku kebijakan lainnya menyelenggarakan forum diskusi untuk menetapkan wilayah ADIZ di Indonesia. Pembahsan mengerucut pada 2 topik yaitu: mengusulkan wilayah ADIZ yang akan ditetapkan oleh pemerintah dan prosedur pesawat udara asing pada saat memasuki wilayah ADIZ. Peserta forum diskusi mengusulkan agar wilayah ADIZ Indonesia idealnya meliputi seluruh wilayah Negara Kesatuan Republik Indonesia, baik wilayah udara dengan kedaulatan maupun wilayah udara yurisdiksi dengan hak berdaulat. ${ }^{20}$

Penetapan ADIZ Indonesia harus mendasarkan pada kedaulatan Indonesia atas wilayah udaranya, penting dipertimbangkan bahwa penetapan ADIZ merupakan salah satu upaya untuk menjaga pertahanan dan keamanan wilayah udara. Apabila usulan peserta forum diskusi tersebut digunakan oleh pemerintah dalam menetapkan ADIZ Indonesia, maka luas wilayah ADIZ Indonesia akan meliputi seluruh wilayah udara nasional. ADIZ Indonesia idealnya dipandang sebagai instrumen mempertahankan diri sesuai dengan Pasal 51 Piagam PBB tentang Hak Bela Diri Negara, tidak dapat dipungkiri nantinya dalam penetapan ADIZ Indonesia, negara tetangga akan

\footnotetext{
19 A Priyatna, Pengantar Hukum Ruang Angkasa Dan Space Treaty (Bandung: Binacipta, 1967).

${ }^{20}$ Marsono, "Konsep Kedaulatan Negara Di Ruang Udara Dan Upaya Penegakan Pelanggaran Kedaulatan Oleh Pesawat Udara Asing."
} 
memberikan pelbagai macam respons mengingat situasi di Laut China Selatan yang sedang memanas antara China dengan negara ASEAN pada umumnya.

Destabilisasi wilayah Laut China Selatan akibat tumpang tindih klaim batas wilayah akan berpotensi menghambat penetapan ADIZ Indonesia, konstelasi politik di Laut China Selatan tentu akan turut mempengaruhi penetapan ADIZ Indonesia. Untuk itu perlu dilakukan komunikasi melalui jalur diplomasi antara pemerintah Indonesia dengan pemerintah negara-negara yang berbatasan langsung dengan Indonesia baik daratan maupun lautan seperti: India, Thailand, Malaysia, Singapura, Vietnam, Philipina, Papua Nugini, Palau, Timor Leste, dan Australia.

Membuka ruang komunikasi dengan negara tetangga mengenai rencana penetapan ADIZ Indonesia oleh pemerintah Indonesia dapat melepas ketegangan yang akan terjadi apabila terjadi penolakan dari negara tetangga yang wilayah daratannya berbatasan langsung dengan Indonesia, politik bebas aktif yang selama ini diusung dan digunakan oleh Indonesia akan menguntungkan proses diplomasi yang dilakukan oleh Kementerian Luar Negeri. Pemerintah Jepang juga menerapkan kebijakan diplomasi dalam mengantisipasi klaim ADIZ China pada tahun 2013, bersamaan dengan peningkatan anggaran belanja pertahanan, pengembangan industri pertahanan, dan modernisasi alat utama sistem persenjataan militer Jepang. ${ }^{21}$

Penetapan ADIZ Indonesia juga dapat melihat kebijakan ADIZ Amerika Serikat, dimana setiap pesawat udara asing yang masuk dan melintasi ADIZ Amerika Serikat tanpa intensi untuk memasuki wilayah udara Amerika Serikat tidak diwajibkan untuk melapor dan

${ }^{21}$ I Gabriela, “Kebijakan Jepang Dalam Mengantisipasi Klaim Air Defence Identification Zone (ADIZ) Oleh Tiongkok," Journal of International Relations 4, no. 3 (2018): 470. 
memberikan rencana penerbangan kepada petugas Federal Aviation Administration (FAA). Kebijakan ini memperlihatkan bahwa ADIZ Amerika Serikat bertindak berdasarkan tujuan utama untuk menjalankan fungsi pertahanan, bukan ekspansi wilayah udara. ${ }^{22}$

Pemahaman tujuan penetapan $A D I Z$ Indonesia sebagai ruang untuk membela diri, menjaga kedaulatan negara, dan mempertahankan wilayah udara harus sampai kepada negara tetangga. Penyampaian informasi dan membangun kepercayaan ini akan menjadi tugas rumah yang berat Kementerian Luar Negeri di tengah dinamika konflik Laut China Selatan dan konstelasi politik antar negara yang menyertainya, informasi penetapan ADIZ Indonesia juga harus terus digaungkan kepada dunia internasional agar ada pengakuan terhadap kedaulatan Indonesia atas wilayah udaranya, pengakuan ini akan mempermudah proses ratifikasi regulasi ruang udara dan wujud eksistensi ADIZ Indonesia di mata Internasional.

\section{KESIMPULAN}

Penetapan ADIZ Indonesia oleh pemerintah memerlukan pelbagai penyempurnaan hukum positif sehingga dalam pelaksanaannya tidak menimbulkan kekaburan dan kekosongan norma. Diajukannya nota keberatan oleh maskapai Ethiopia Airlines pada tahun 2019 atas tindakan pemaksaan mendarat dan penanganan pasca tindakan yang lebih dari 3 hari akibat ketidak jelasan regulasi, cukup menjadi pengingat dan momentum bahwa asas legalitas yang menjadi dasar hukum positif di Indonesia tidak dapat dikesampingkan dalam upaya menjaga kedaulatan, pertahanan, dan keamanan wilayah udara Indonesia. Upaya penetapan ADIZ Indonesia juga harus dibarengi dengan peningkatan kualitas sumber daya manusia khususnya di TNI AU dan petugas sipil Air Traffic

\footnotetext{
${ }^{22}$ R. A Nugraha, “Polemik Air Defence Identification Zone,” Hukumonline.Com.
} 
Control, mengingat sumber daya manusia menjadi tumpuan utama dalam pengoperasian satuan radar dan pengelolaan lalu lintas udara disamping adanya teknologi. Pemenuhan jumlah ideal 32 radar harus menjadi prioritas tertinggi pemerintah sebelum menetapkan ADIZ Indonesia, tidak akan bekerja secara maksimal pelbagai faktor pertahanan udara apabila pesawat udara asing yang memasuki wilayah udara Indonesia tidak dapat diketahui oleh Kohanudnas untuk kemudian dilakukan tindakan sesuai PP Nomor 4 Tahun 2018 tentang Pengamanan Wilayah Udara Republik Indonesia.

Penetapan ADIZ Indonesia oleh pemerintah harus dikomunikasikan kepada negara tetangga yang berbatasan langsung dengan Indonesia melalaui jalur diplomatik, hal ini dilakukan untuk mengurangi rasa curiga, ketegangan, dan membuka ruang komunikasi dua arah sehingga ada kesepahaman bersama mengenai konsep ADIZ Indonesia. Situasi di Laut China Selatan juga akan mempengaruhi dinamika penetapan ADIZ Indonesia kedepannya, mengingat konstelasi politik antar negara yang tengah berkonflik di Laut China Selatan masih belum stabil usai klaim teritorial atas wilayah Laut China Selatan oleh negara China. Pemerintah dapat melakukan publikasi secara terus-menerus kepada dunia Internasional mengenai penetapan ADIZ Indonesia untuk mengenalkan dan menggalang dukungan terhadap kedaulatan wilayah udara Indonesia, pengakuan Internasional menjadi penting untuk mempermudah proses ratifikasi regulasi ruang udara di Indonesia.

\section{DAFTAR PUSTAKA}

Ant. "Sudah Saatnya Indonesia Memiliki Adiz." Media Indonesia. Jakarta, 2018.

Chairil, T. "Cek Fakta: 19 Titik Di Udara Dan 11 Titik Di Maritim, Apakah Sistem Radar Yang Disebut Jokowi Sudah Efektif?" The 


\section{Conversation.Com.}

Gabriela, I. “Kebijakan Jepang Dalam Mengantisipasi Klaim Air Defence Identification Zone (ADIZ) Oleh Tiongkok." Journal of International Relations 4, no. 3 (2018): 470.

Halim, D. “Sepanjang 2018 TNI AU Catat Ada 127 Kasus Pelanggaran Wilayah Udara Nasional." Kompas. Jakarta, December 2018.

Handini. "Kedaulatan Wilayah Udara Di Atas Alur Laut Kepulauan Indonesia (ALKI)." Jurnal Rechts Vinding 8, no. 2 (2019): 280.

Kusumatmadja, M. Pengantar Ilmu Hukum Internasional. Bandung: Putra Bardin, 1999.

Lainatussara. "Pentingnya Air Defence Identification Zone Di Indonesia." Kanun Jurnal Ilmu Hukum 21, no. 3 (2019): 460.

Markas Besar TNI AU. Buku Panduan Perwira Hukum Tentara Nasional Indonesia Angkatan Udara. Jakarta: Diskumau, 2000.

Marsono, D. D. “Konsep Kedaulatan Negara Di Ruang Udara Dan Upaya Penegakan Pelanggaran Kedaulatan Oleh Pesawat Udara Asing." Jurnal Pertahanan \& Bela Negara 8, no. 2 (2018): 2.

Nugraha, R. A. “Menyempurnakan Hukum Positif Pengamanan Wilayah Udara Nasional." Hukumonline.Com.

- - -. "Polemik Air Defence Identification Zone." Hukumonline.Com.

Priyatna, A. Pengantar Hukum Ruang Angkasa Dan Space Treaty. Bandung: Binacipta, 1967.

Risdiarto, D. “Kendala Hukum Penindakan Terhadap Pesawat Udara Sipil Asing Tidak Berizin Yang Memasuki Wilayah Udara Indonesia." Jurnal Legislasi Indonesia 16, no. 3 (2019): 363.

Setiani, B. "Konsep Kedaulatan Negara Di Ruang Udara Dan Upaya Penegakan Pelanggaran Kedaulatan Oleh Pesawat Udara Asing." Jurnal Konstitusi 14, no. 3 (2017).

Sonata, Depri Liber. “METODE PENELITIAN HUKUM NORMATIF DAN 
EMPIRIS: KARAKTERISTIK KHAS DARI METODE MENELITI HUKUM." FIAT JUSTISIA:Jurnal Ilmu Hukum (2015).

Supriadhie, A. Penerapan Air Defence Identification Zone (ADIZ) Di Wilayah Ruang Udara Oleh Negara. Jakarta, 2016.

Taher, A. P. “Mekanisme Force Down Disusun Atasi Gugatan Seperti Dari Ethiopia." Tirto.Id.

Tentara Nasional Indonesia Angkatan Udara. “Tugas Kohanudnas.” TniAu.Mil.Id.

Yudhistira, A. "Over-The-Horizon Radar (OTHR) Untuk Menjaga Wilayah Udara Dan Laut Indonesia." Jurnal Pertahanan 5, no. 2 (2015): 139. 